\title{
Characterization of a Conditional Mutant with Altered Envelope Showing pH-dependent Morphology and Temperature-dependent Division
}

\author{
By G. SATTA AND ROBERTA FONTANA \\ Institute of Microbiology, University of Genoa, 16132 Genoa, Italy
}

(Received I 9 February 1973)

SUMMARY

\begin{abstract}
The properties of a conditional mutant of Klebsiella pneumoniae (Mir $\mathrm{M}_{7}$ ) are described. The mutant has a $\mathrm{pH}$-dependent disturbance of morphology and a temperature-dependent disturbance of division. At $\mathrm{pH} 7$ the mutant grows as cocci and at $4 \mathrm{I}{ }^{\circ} \mathrm{C}$ (restrictive temperature) division is inhibited. At acid $\mathrm{pH}$ and restrictive temperature, filaments are formed. At $\mathrm{pH} 7$ and permissive temperature, polymorphous cocci are obtained. At $\mathrm{pH} 7$ and $4 \mathrm{I}{ }^{\circ} \mathrm{C}$, giant polymorphous cells are formed. The inhibition of division is phenotypically reverted by $0.05 \mathrm{M}-\mathrm{Mg}^{2+}$, $0 . \mathrm{M}^{\mathrm{N}} \mathrm{Na}^{+}$or $0.4 \mathrm{M}$-sucrose. Seventeen revertants were isolated having exactly the same characteristics as the wild-type Klebsiella, so it seems that only one mutation is responsible for the different disturbances of the mutant. The possibility of membrane damage on which the morphology and division disturbances may depend is discussed.
\end{abstract}

\section{INTRODUCTION}

The interdependence between bacterial functions and structures such as the cell membrane is becoming evident (Hirota, Mordoh \& Jacob, I970; Rogers, 1970). The physical integrity and replication of DNA, for example, may depend on the state of the cytoplasmic membrane (Schachtele, Anderson \& Rogers, 1968; Shapiro, Siccardi, Hirota \& Jacob, I970; Siccardi, Shapiro, Hirota \& Jacob, I97I). Inhibition of DNA replication can cause changes in membrane protein composition (Inouye \& Pardee, I970; Walker \& Pardee, I968) and inhibition of septum formation (Walker \& Pardee, 1968). The timing of action of some hydrolases located in the membrane has been reported to be correlated with genome replication (Schwarz, Asmus \& Frank, I 969). The inhibition of septation can be caused by partial inhibition of the synthesis of mucopeptide (Rogers, 1970). Slight or gross alteration of the wall is frequently associated with an aberrant invagination of the septum (Boylan \& Mendelson, 1969; Cole, Popkin, Boylan \& Mendelson, I970; Grula \& King, 1970; Rogers, MacConnell \& Burdett, 1970).

A possible hypothesis is that in such relationships a key role is played by a limited area in the membrane which, according to various models (Jacob, Brenner \& Cuzin, 1963; Donachie \& Begg, 1970), might be the site at which the genome replicates, growth of the cell wall and the cytoplasmic membrane take place, and septum invagination occurs. Some experimental data already support this possibility (Jacob et al. I963; Ryter, I967; Donachie \& Begg, I970; Ryter, I97I) and further support could be obtained from the isolation of conditional membrane mutants damaged in more than one of these functions.

Meloni \& Monti-Bragadin (1962) have isolated in this laboratory a strain of Klebsiella pneumoniae (Mir $\mathrm{M}_{7}$ ) which shows a rod-shaped morphology at $\mathrm{pH} 5.5$ and a coccal morphology at $\mathrm{pH} 7$. Recently, we have noticed that this mutant shows disturbances of 
the membrane and of cell division dependent on conditions of incubation (Satta, Schito \& Meloni, I969). This paper records further observations on these phenomena.

\section{METHODS}

Bacterial strains. Mir $\mathrm{M}_{7}$, a morphological mutant of Klebsiella pneumoniae, has been isolated and described by Meloni \& Monti-Bragadin (I962). Mir AI2 is a revertant with the physiological and morphological characteristics of the wild-type Klebsiella pneumoniae (G. Satta \& R. Fontana, unpublished).

Media and $p H$. PL medium contained $(\mathrm{g} / \mathrm{l})$ : peptone, 10 ; lactose, $10 ; \mathrm{K}_{2} \mathrm{HPO}_{4}, 0.3$; $\mathrm{KH}_{2} \mathrm{PO}_{4}, 0 . \mathrm{I} ; \mathrm{Na}_{2} \mathrm{SO}_{4}, 0.2$. The $\mathrm{pH}$ varied between 5.3 and 5.7 and was brought to the desired value by adding $\mathrm{NaOH}$ or $\mathrm{HCl}$. In the experiment at constant $\mathrm{pH}$, the $\mathrm{pH}$ was measured every $30 \mathrm{~min}$, and when necessary adjusted by a calculated amount of $\mathrm{HCl}$ or $\mathrm{NaOH}$.

Preparation of round and rod-shaped cells. When Mir M7 was grown or maintained on a slant of $\mathrm{PL}$ agar at $\mathrm{pH} 7$ and $37^{\circ} \mathrm{C}$ the cells were round. To yield round cells for harvesting, growth was on PL at $\mathrm{pH} 7$ and $37^{\circ} \mathrm{C}$, to an optical density (O.D.) of 0.5 as measured by a Beckman DU spectrophotometer at $650 \mathrm{~nm}$. Rod-shaped cells were obtained by transferring a loopfull of $\mathrm{Mir} \mathrm{M}_{7}$ from the slant into $\mathrm{PL}$ at $\mathrm{pH} 5.5$, and incubating at $30{ }^{\circ} \mathrm{C}$ for $36 \mathrm{~h}$. A $2 \mathrm{ml}$ portion of this culture was transferred to $\mathrm{PL}$ at $\mathrm{pH} 5.5$ and incubated at $30^{\circ} \mathrm{C}$ to an O.D. of 0.5 . Cells of either shape were harvested by centrifugation at $4000 \mathrm{~g}$ for $5 \mathrm{~min}$.

Revertants. Three techniques were used to isolate revertants. One exploited the relative fragility of mutant Mir M7 compared with the wild-type Klebsiella when subjected to repeated freezing and thawing. The second utilized lysis of the round cells by DL-methionine in PL at $\mathrm{pH} 5.5$. The third technique employed the inhibition of division at $42{ }^{\circ} \mathrm{C}$.

Freezing and thawing. A log phase culture of $\mathrm{Mir}_{7}$ in $\mathrm{PL} \mathrm{pH}_{7}$ was harvested and resuspended in $0.84 \mathrm{M}-\mathrm{NaCl}$ at $2 \times 10^{8}$ cells $/ \mathrm{ml}$. The solution was rapidly and repeatedly frozen and thawed till the O.D. of the suspension had fallen to $10 \%$ of the original value. A $10 \mathrm{ml}$ portion of this suspension was centrifuged for $5 \mathrm{~min}$ at $4000 \mathrm{~g}$. The pellet was resuspended and subdivided into 100 tubes of $\mathrm{PL} \mathrm{pH} 7$ which were incubated at $37^{\circ} \mathrm{C}$ until the O.D. reached 0.5 . The tubes were frozen and thawed till the bacterial suspension was clarified, after which the suspension was again incubated at $37^{\circ} \mathrm{C}$ for $4 \mathrm{~h}$. All the tubes in which growth had occurred were examined and those cultures containing rod-shaped cells were plated on $\mathrm{PL}$ agar $\mathrm{pH} 7$ plates. From each isolation a colony of rod-shaped cells was chosen and transferred to a slant for subsequent experiments.

Growth in PL at $42{ }^{\circ} \mathrm{C}$. About $4 \times 10^{7}$ cells were spread on each of $30 \mathrm{PL}$ agar $\mathrm{pH} 5.5$ plates and incubated at $42{ }^{\circ} \mathrm{C}$ for 72 to $96 \mathrm{~h}$. An average of five colonies from each plate was transferred and incubated again for $24 \mathrm{~h}$. All the colonies that survived this last transfer were grown in PL pH 5.5 and incubated at $42{ }^{\circ} \mathrm{C}$ for $36 \mathrm{~h}$. Cultures whose cells were rodshaped were diluted to about four cells $/ \mathrm{ml}$ and $0^{\circ} \mathrm{I} \mathrm{ml}$ samples were transferred to $\mathrm{PL}$ and incubated at $42{ }^{\circ} \mathrm{C}$ for $36 \mathrm{~h}$. A turbid tube containing rod-shaped cells from each diluted sample was transferred to a slant for subsequent experiments.

Growth in PL pH 5.5 containing DL-methionine. Round cells prepared and harvested as indicated were transferred to 200 tubes containing $5 \mathrm{ml}$ of $\mathrm{PL} \mathrm{pH} 5.5$ plus DL-methionine $(0.3 \mathrm{mg} / \mathrm{ml})$ to give a final O.D. of $0 \cdot \mathrm{I}$. The tubes were incubated at $37{ }^{\circ} \mathrm{C}$ and after $\mathrm{I} 6 \mathrm{~h}$, tubes in which the O.D. had dropped to below 0.020 were selected and incubated again for $\mathrm{I} 2 \mathrm{~h}$ at the same temperature. Turbid tubes were diluted to final concentration of about 

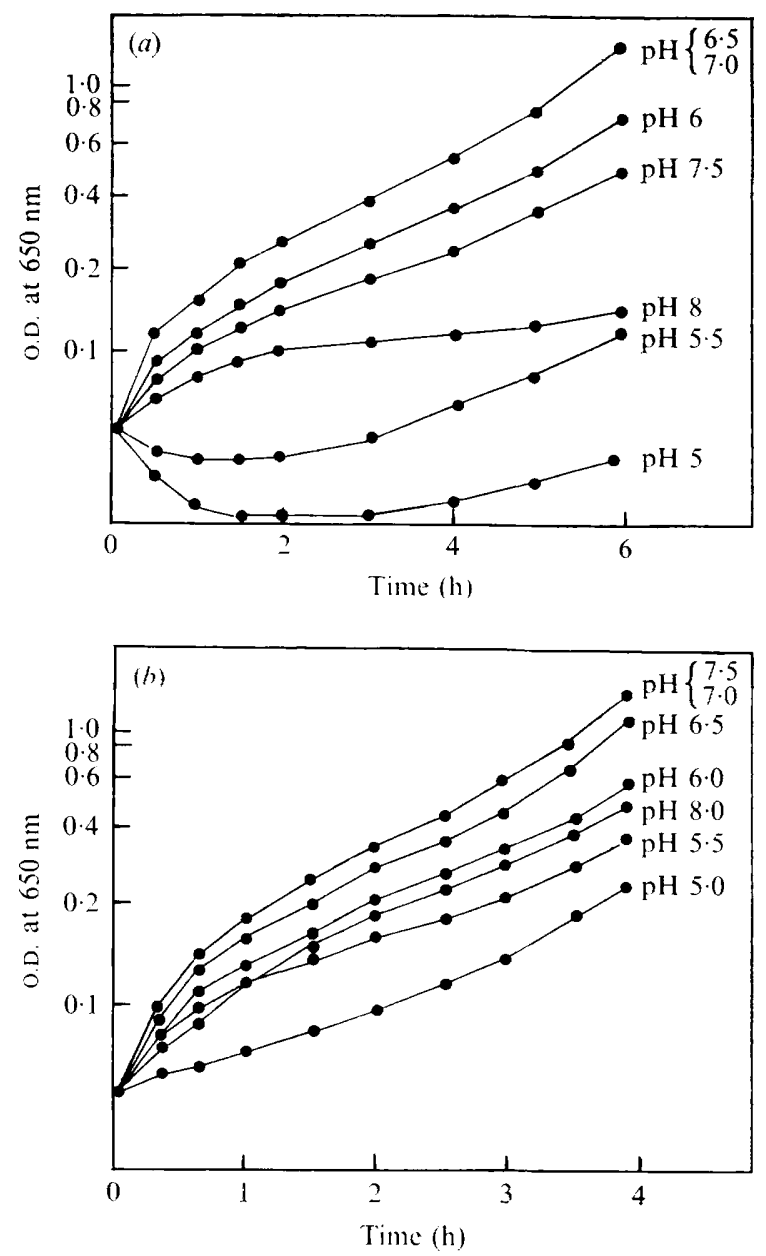

Fig. 1. Effect of various incubation pH's on the growth of (a) Klebsiella pneumoniae Mir $\mathrm{M}_{7}$ and (b) Mir A 12 in PL medium. Equal quantities of round cells of Mir M7 or of Mir A1 2 in $\log$ phase, were transferred to each of the media and incubated at $37{ }^{\circ} \mathrm{C}$ without shaking. At regular time intervals the O.D. was measured. The $\mathrm{pH}$ was kept constant as described in Methods.

four cells $/ \mathrm{ml}$ and $\mathrm{O} \cdot \mathrm{I} \mathrm{ml}$ samples were inoculated into each of $\mathrm{I} 5$ tubes. After $\mathrm{I} 2 \mathrm{~h}$ incubation at $37{ }^{\circ} \mathrm{C}$ a turbid tube for each series of $\mathrm{I} 5$ tubes was taken at random; the cellular morphology was examined and a loopfull was transferred to a slant for subsequent experiments.

\section{RESULTS}

\section{Growth and morphology at different $p H$ values}

Fig. I and 2 and Table I show the growth curves and the morphology of round cells of the mutant Mir M7 and of the strain Mir AI 2 (a revertant with the physiological and morphological characteristics of the wild-type Klebsiella pneumoniae) in PL medium at various $\mathrm{pH}$ values. At present we have no explanation for the non-linearity of these growth curves. Preliminary results suggest that the reduction in growth rate between the second and fourth hour at $\mathrm{pH} 6,7$ and 7.5 might be due to the induction of a bacteriophage. 

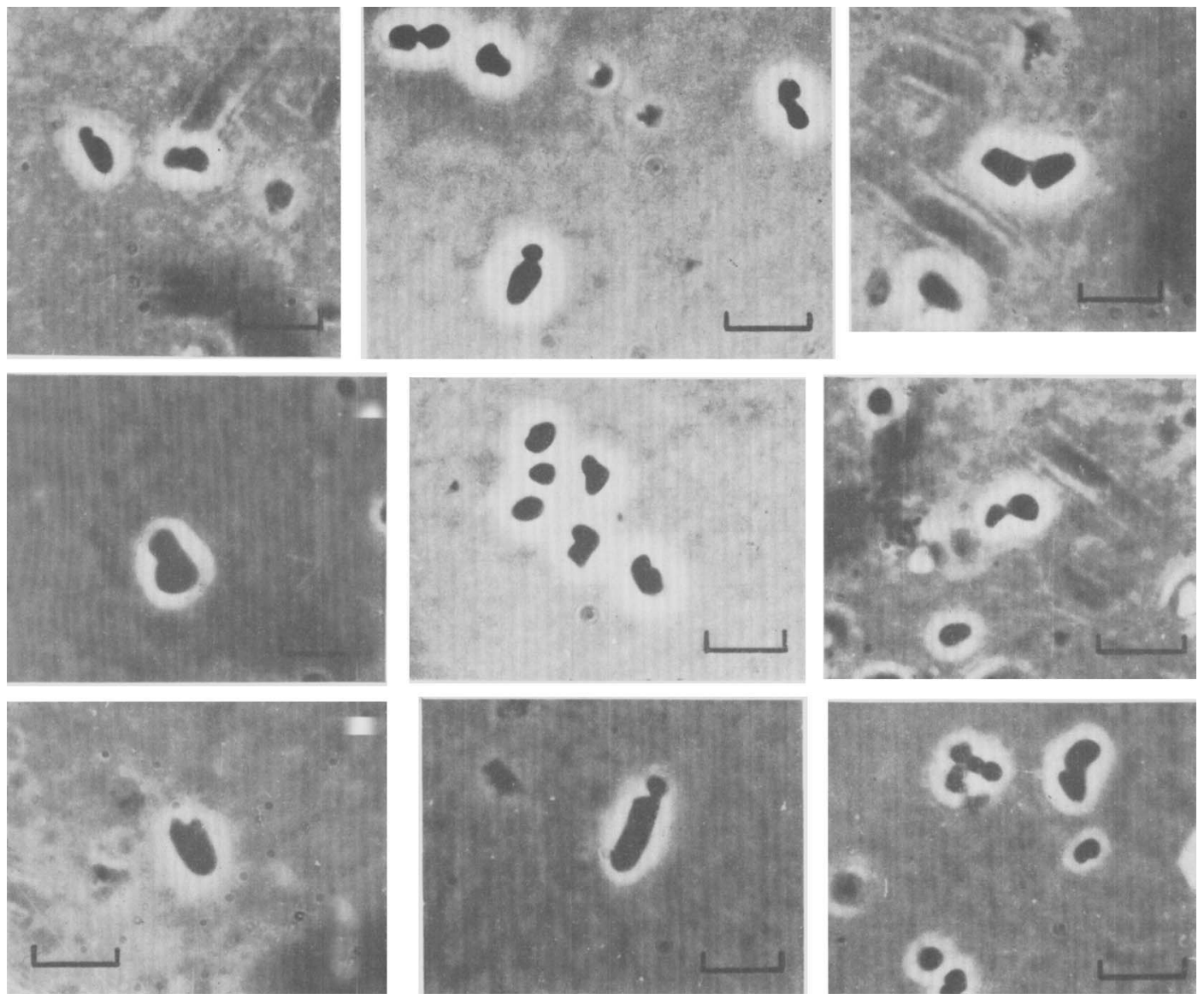

Fig. 2. Polymorphism and atypical divisions in cells of mutant Mir M7. Cells of Mir M7 grown in $\mathrm{PL} \mathrm{pH} 7$ to $\log$ phase, were transferred to a $\mathrm{PL} \mathrm{pH} 7$ medium and incubated at $37^{\circ} \mathrm{C}$ without shaking. The $\mathrm{pH}$ was kept constant as described in Methods. Scale markers represent $8 / \mathrm{m}$.

However, the growth curves of the strain Mir $\mathrm{A}_{2} 2$ and of the mutant Mir $\mathrm{M}_{7}$ between $\mathrm{pH} 6$ and 8, are similar.

Strain Mir $\mathrm{M}_{7}$ can grow at $\mathrm{pH}$ values between 5 and 8 with an optimum between 6.5 and 7 (Fig. I). It is very sensitive to alkaline $\mathrm{pH}$ values; it grows badly at $\mathrm{pH} 7 \cdot 5$, the optimum for Mir Al 2 strain, and is inhibited more by $\mathrm{pH}$ values around 8 than is the Mir AI 2 strain (Fig. I). At pH values between 6 and 8 the mutant and Mir Ai 2 strain differ only in growth

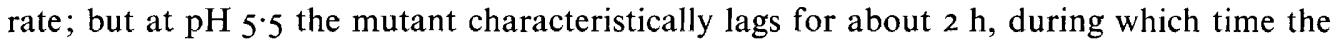
turbidity drops Io to $20 \%$.

At low $\mathrm{pH}$ values the coccal-shaped cells become rod-shaped after 3 to $6 \mathrm{~h}$ incubation (Table $\mathrm{I}$ ). The highest $\mathrm{pH}$ value for the transition to the rod morphology is $\mathrm{pH} 6.5$. At lower $\mathrm{pH}$ values the transition is more rapid and longer rods are formed. At the $\mathrm{pH}$ optimum for growth, cells remain roundish and most of the divisions are atypical (Fig. 2). At alkaline $\mathrm{pH}$ values the cells become uniformly round, and the higher the $\mathrm{pH}$, the bigger they ultimately become, until at $\mathrm{pH} 8$, they look like spheroplasts. 


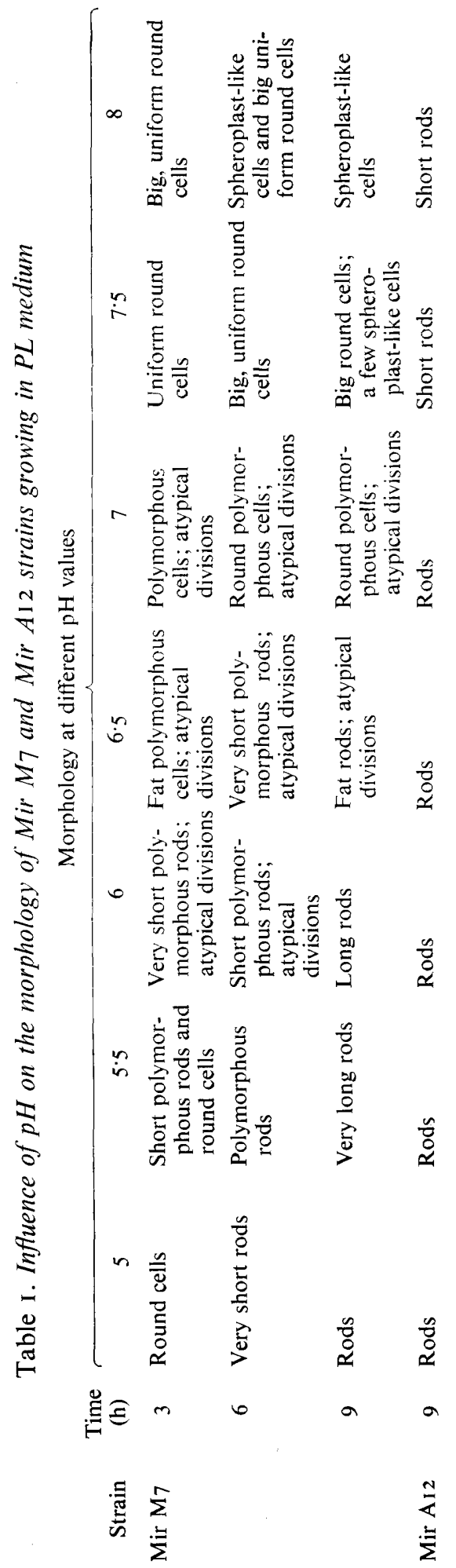



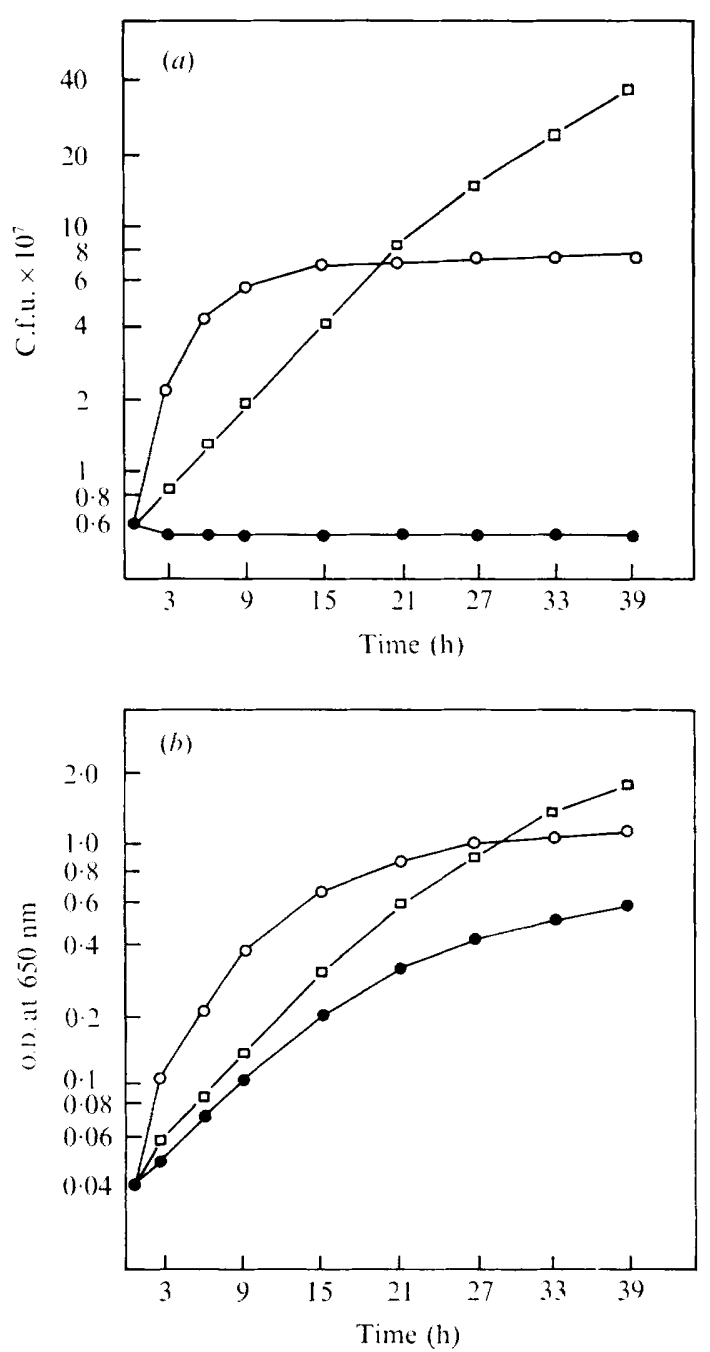

Fig. 3. Effect of incubation temperature on rod-shaped cells. Rods of mutant Mir M7 were transferred into $\mathrm{PL}$ pH 5.5 medium. The culture was subdivided into 3 parts which were incubated respectively at $30{ }^{\circ} \mathrm{C}(\square-\square), 37^{\circ} \mathrm{C}(\mathrm{O}-\mathrm{O})$ and $4 \mathrm{I}{ }^{\circ} \mathrm{C}(-)$ without shaking. At regular time intervals $(a)$ the colony forming units and $(b)$ O.D. were determined.

The effect of temperature on growth and morphology in PL at pH 5.5

The effect of temperature on growth and morphology of round and rod-shaped cells growing at $\mathrm{pH} 5.5$ is illustrated in Fig. 3 and 4 , and Table 2. At $30{ }^{\circ} \mathrm{C}$ both round and rod-shaped cells grow and divide normally, and after growth for $48 \mathrm{~h}$ they cannot be distinguished from the original strain (Satta \& Fontana, 1974). At $37^{\circ} \mathrm{C}$ round and rod-shaped cells grow and divide regularly for 10 to $14 \mathrm{~h}$. Subsequently the viable count remains constant and the O.D. continues to increase. Both the cocci and rods form filaments. At $4 \mathrm{I}{ }^{\circ} \mathrm{C}$ growth is always less, and round and rod-shaped cells differ in behaviour. Within the first four hours, the former drop slightly in O.D. and 70 to $80 \%$ in viable count. From then on, the O.D. slowly increases for $\mathrm{I} 2 \mathrm{~h}$, whereas the viable count remains constant. 

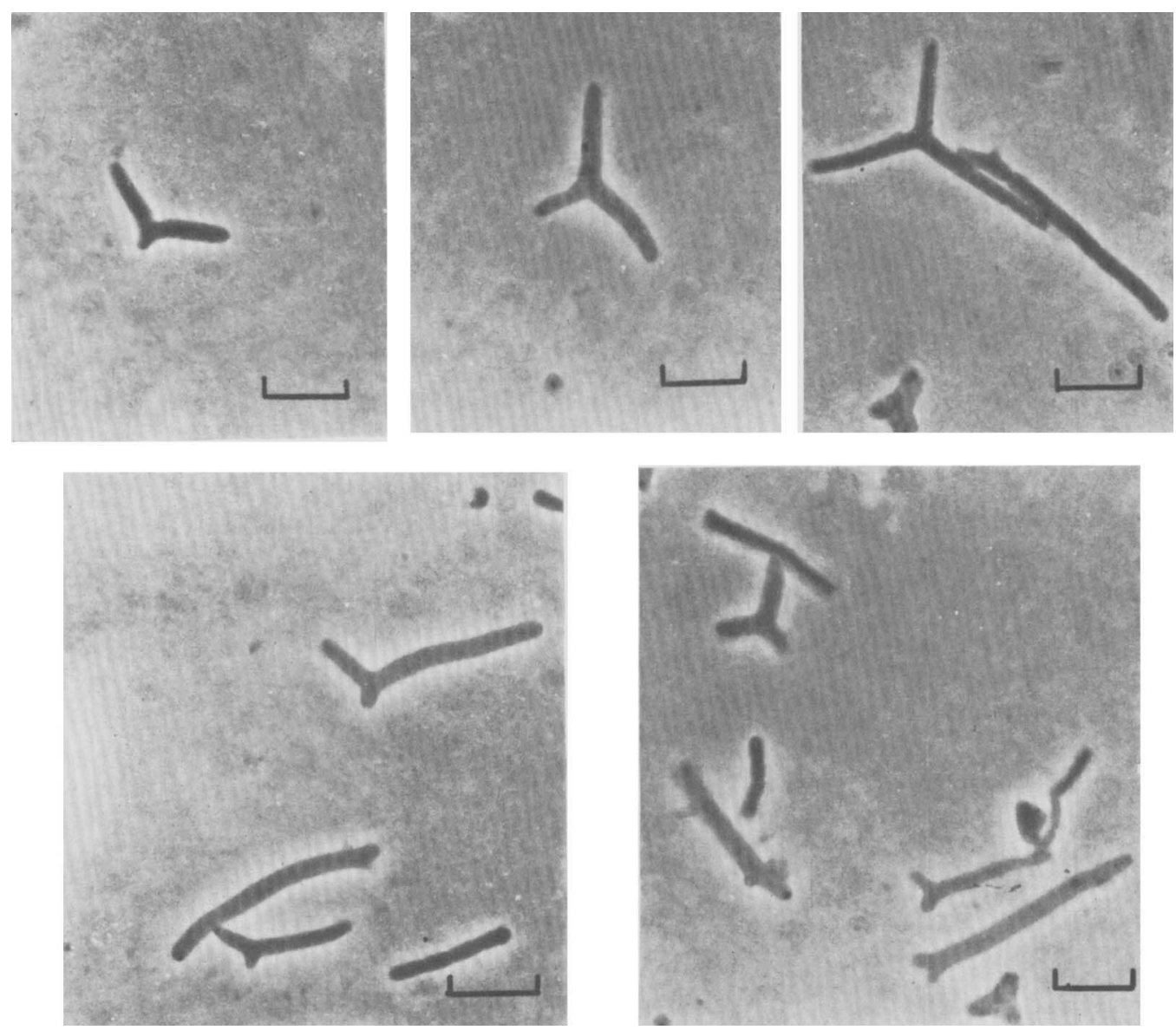

Fig. 4. Filaments originating from round cells of $\mathrm{Mir}_{7}$ incubated in $\mathrm{PL}$ pH 5.5 medium at $4 \mathrm{I}^{\circ} \mathrm{C}$. Round cells prepared as described in Methods were transferred to $\mathrm{PL}$ pH 5.5 and incubated at $4 \mathrm{I}{ }^{\circ} \mathrm{C}$ without shaking. The photos were taken after $8 \mathrm{~h}$ incubation. Scale markers represent I $2 \mu \mathrm{m}$.

A large percentage of cells stay rod-shaped for the whole experiment (probably cells which are dead), whereas others lengthen, forming filaments after about $10 \mathrm{~h}$. The filaments sometimes become very long, and are always fatter than normal rods and polymorphous (Fig. 4). Cells incubated as rods at $4 \mathrm{I}{ }^{\circ} \mathrm{C}$ grow from the beginning of incubation. The O.D. increases during the whole period of incubation; the viable count maintains its original value for $24 \mathrm{~h}$, before decreasing slightly (Fig. 4). With continued incubation the rods grow longer and longer, forming long uniform filaments which have the same diameter as normal rods.

\section{Growth and morphology at $4 \mathrm{I}^{\circ} \mathrm{C}$ in $\mathrm{PL}$ at $\mathrm{pH} 7$}

Fig. 5 and Table 2 show the morphological evolution of round cells in $\mathrm{PL} \mathrm{pH} 7$ at $4 \mathrm{I}{ }^{\circ} \mathrm{C}$. Even at this $\mathrm{pH}$ about 50 to $70 \%$ of the round cells die during the first few hours and the viable count does not subsequently increase. The O.D. drops during the first few hours after which it shows a slow increase. Fifty to $80 \%$ of the population are round cells which remain unaltered all through the experiment and are most probably dead cells. 
Table 2. Effect of temperature on the morphological evolution of the round and rod-shaped cells of Mir $\mathrm{M}_{7}$ incubated at $\mathrm{pH}$ values 5.5 and 7

\begin{tabular}{|c|c|c|c|c|}
\hline \multirow{2}{*}{$\begin{array}{c}\text { Original } \\
\text { morphology }\end{array}$} & \multirow{2}{*}{$\begin{array}{l}\text { Incubation } \\
\text { time } \\
\text { (h) }\end{array}$} & \multicolumn{3}{|c|}{ Morphology at different incubation temperatures } \\
\hline & & $30^{\circ} \mathrm{C}$ & $37^{\circ} \mathrm{C}$ & $4 I^{\circ} \mathrm{C}$ \\
\hline \multirow[t]{3}{*}{ Rods at $\mathrm{pH} 5.5$} & 8 & Uniform rods & Uniform rods & Uniform filaments \\
\hline & 14 & Uniform rods & $\begin{array}{l}\text { Filaments and uniform } \\
\text { long rods }\end{array}$ & Uniform long filaments \\
\hline & 48 & Uniform rods & $\begin{array}{l}\text { Uniform very long } \\
\text { filaments }\end{array}$ & Long filaments \\
\hline \multirow[t]{3}{*}{$\begin{array}{l}\text { Round cells at } \\
\text { pH } 5.5\end{array}$} & 8 & Polymorphous rods & Long polymorphous rods & $\begin{array}{l}\text { Fat and polymorphous } \\
\text { short filaments and } \\
\text { single round cells }\end{array}$ \\
\hline & 14 & Uniform rods & $\begin{array}{l}\text { Polymorphous filaments } \\
\text { and long rods }\end{array}$ & $\begin{array}{l}\text { Fat polymorphous and } \\
\text { diaphanous filaments }\end{array}$ \\
\hline & 48 & Uniform rods & Very long filaments & \\
\hline \multirow[t]{2}{*}{$\begin{array}{l}\text { Round cells at } \\
\text { pH } 7\end{array}$} & 8 & $\begin{array}{l}\text { Round polymorphous } \\
\text { cells }\end{array}$ & $\begin{array}{l}\text { Round polymorphous } \\
\text { cells }\end{array}$ & $\begin{array}{l}\text { Big amorphous cells } \\
\text { and round cells }\end{array}$ \\
\hline & I4 & $\begin{array}{l}\text { Round polymorphous } \\
\text { cells }\end{array}$ & $\begin{array}{l}\text { Round polymorphous } \\
\text { cells }\end{array}$ & $\begin{array}{l}\text { Giant amorphous cells } \\
\text { and round cells }\end{array}$ \\
\hline
\end{tabular}
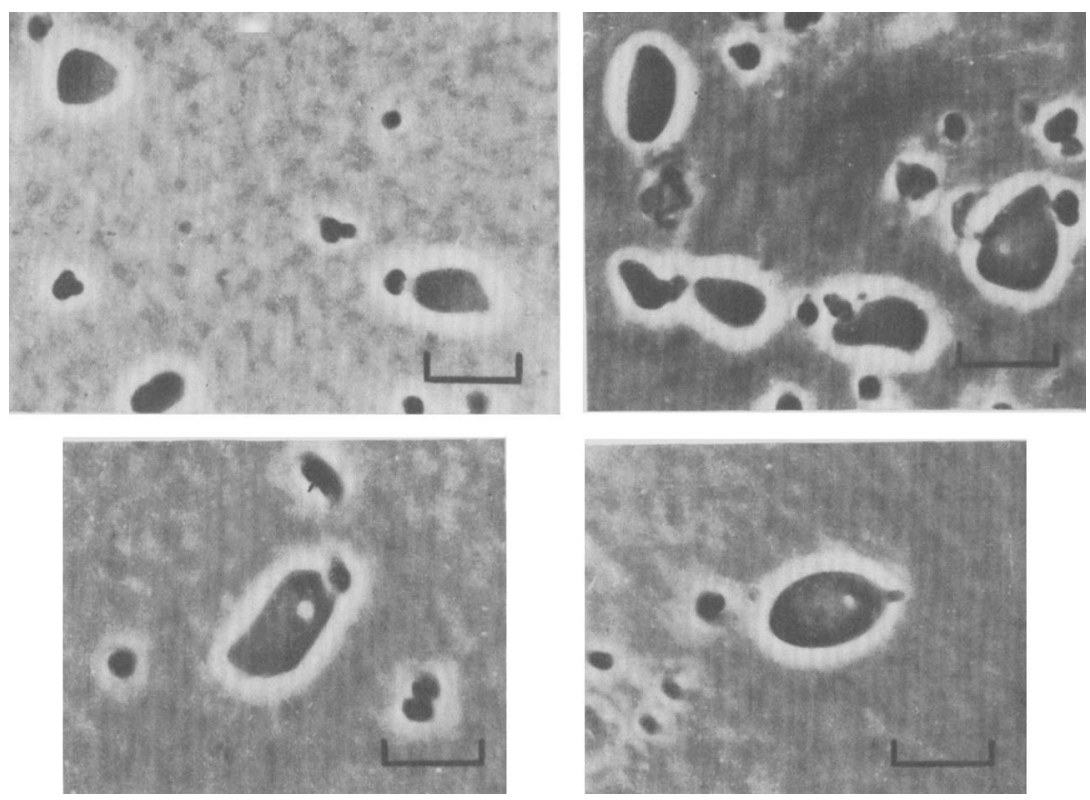

Fig. 5. Giant and monstrous cells originating from round cells incubated in PL pH 7 medium at $4 \mathrm{I}{ }^{\circ} \mathrm{C}$. The $\mathrm{pH}$ was maintained constant as described in Methods. Scale markers represent $15 \mu \mathrm{m}$.

The remaining cells show a progressive increase in diameter, forming giant and amorphous cells which can reach an average diameter 4 to 6 times greater than the original (Fig. 5).

Effect of sucrose, $\mathrm{MgCl}_{2}$ and $\mathrm{NaCl}$ on the growth in acid medium at $37{ }^{\circ} \mathrm{C}$ and $4 \mathrm{I}{ }^{\circ} \mathrm{C}$

High osmolarity and some ions can protect fragile cells (MacQuillen, 1960). A study has been made of the growth of round and rod-shaped cells in $\mathrm{PL} \mathrm{pH} 5.5$ containing different concentrations of sucrose, $\mathrm{MgCl}_{2}$ or $\mathrm{NaCl}$, at 37 and $4 \mathrm{I}{ }^{\circ} \mathrm{C}$. At $37^{\circ} \mathrm{C}$ (Fig. 6) 


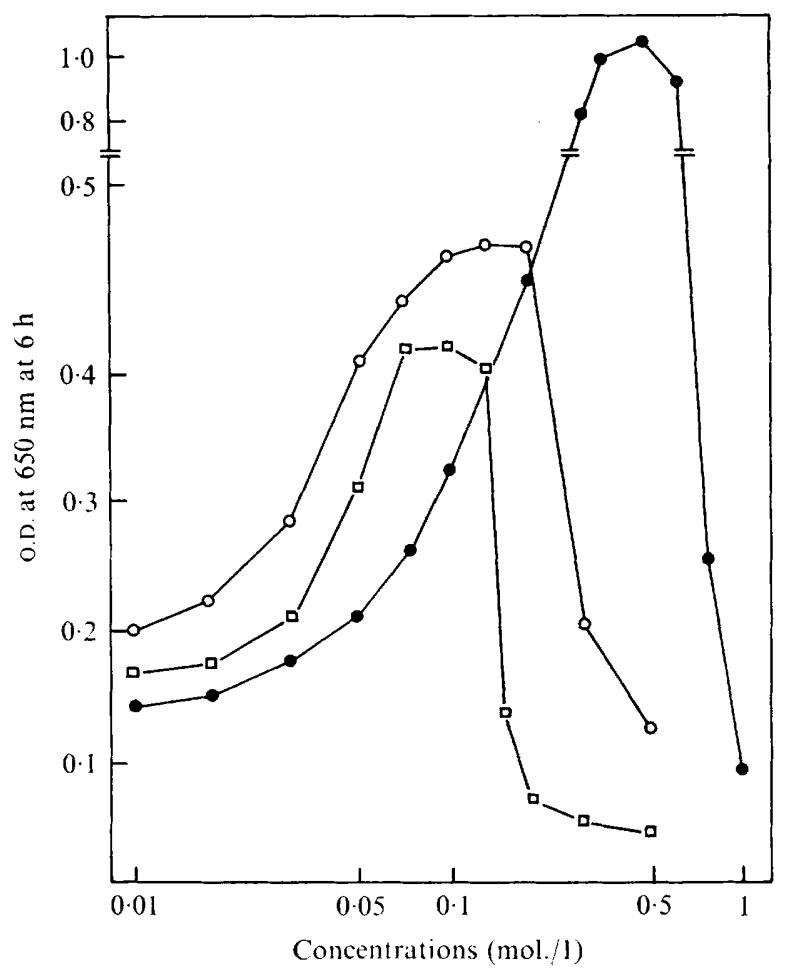

Fig. 6. Effect of the various sucrose (--O), $\mathrm{NaCl}(\mathrm{O}-\mathrm{O})$ and $\mathrm{MgCl}_{2}(\square-\square)$ concentrations on the growth of round cells of Mir M7 incubated in PL pH 5.5 medium. Round cells of Mir $\mathrm{M}_{7}$ in $\log$ phase were transferred into PL pH 5.5 medium containing each of these three substances at various concentrations between $\mathrm{I} M$ and $\mathrm{I} \times 10^{-2} \mathrm{M}$. The original O.D. was the same in all samples. After about $6 \mathrm{~h}$ of incubation without shaking, the O.D. was determined.

all the substances tested abolished the typical $2 \mathrm{~h}$ lag before growth, led to an increase in the growth rate, and prevented the formation of filaments which otherwise appear after Io to $\mathrm{I} 4 \mathrm{~h} . \mathrm{Mg}^{2+}$ ions were found to have their maximum efficiency at a molarity between $5 \times 10^{-2}$ and $\mathrm{I} \times \mathrm{IO}^{-1}$, while sucrose has its maximum effect on growth rate at $4 \times 1 \mathrm{O}^{-1} \mathrm{M}$, having a negligible effect at $5 \times \mathrm{IO}^{-2}$ to $1 \times \mathrm{IO}^{-1} \mathrm{M}$ (Fig. 6). At $4 \mathrm{I}{ }^{\circ} \mathrm{C}$, sucrose, $\mathrm{Mg}^{2+}$ and $\mathrm{Na}^{+}$ions are effective at the same respective concentrations. They are able to prevent the drop in O.D. and viable count, and the $4 \mathrm{~h}$ lag before growth, all of which are typical of round cells in the acid medium. They also overcome the inhibition of division of rod-shaped and round cells. Fig. 7 shows that in the presence of $0.4 \mathrm{M}$-sucrose, $0.1 \mathrm{M}-\mathrm{Na}^{+}$or $0.05 \mathrm{M}-\mathrm{Mg}^{2+}$, both the O.D. and the viable count of cultures inoculated with rods in PL pH 5.5 increase immediately and in parallel.

\section{Effect of deoxycholate and spermine}

The behaviour of the mutant Mir M7 was studied in the presence of deoxycholate, which can lyse cells with damaged membranes (Nagel de Zwaig \& Luria, 1967; Hirota et al. 1969; Hirota et al. 1970; Rolfe \& Onodera, I97I), and of spermine, which protects membranes (Cohen \& Lichtenstein, 1960; Mager, 1959 $a, b$; Puck, 1960). The concentration of deoxycholate inhibiting growth of the mutant is one fifth of the minimum concentration that has any significant inhibitory effect on the growth of the wild type (Fig. 8). Spermine $\left(5 \times 10^{-3} \mathrm{M}\right)$ 

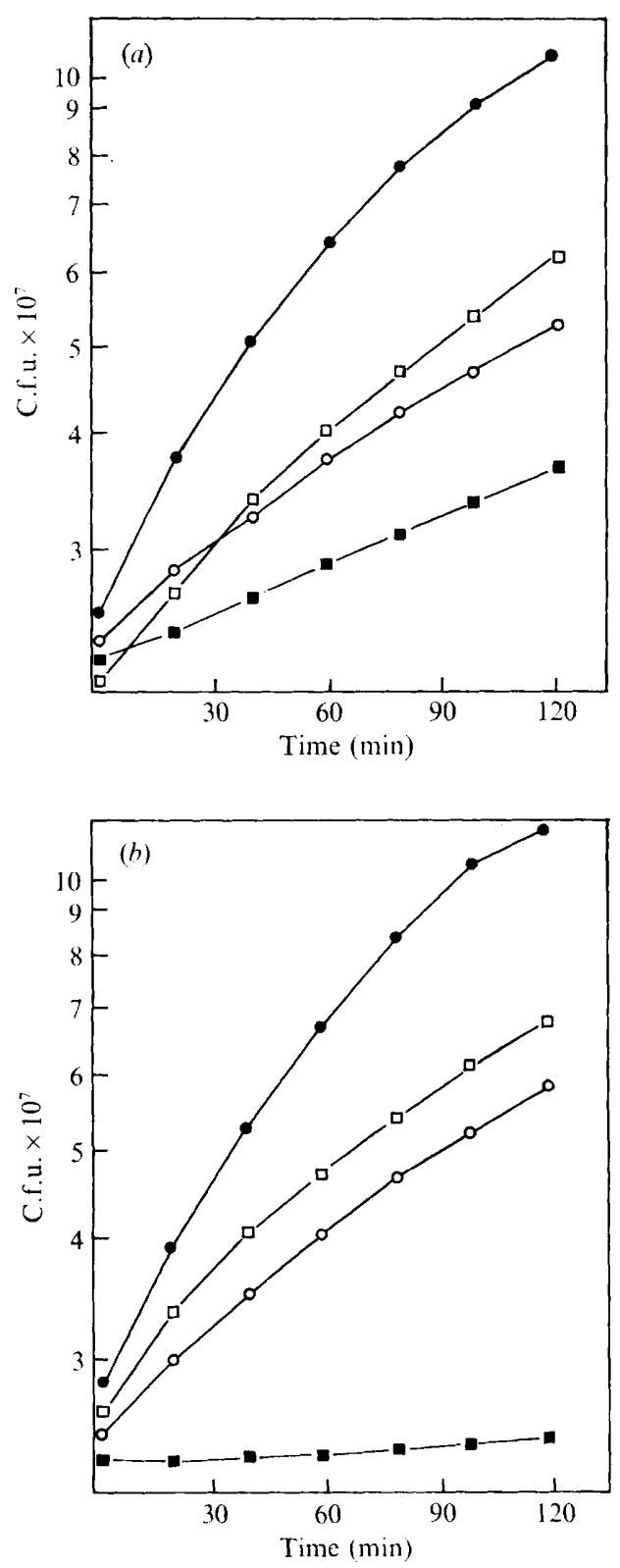

Fig. 7. Effect of sucrose, $\mathrm{Mg}^{2+}$ and $\mathrm{Na}^{+}$on the growth of rods. Cells of mutant $\mathrm{Mir} \mathrm{M} 7$ in log phase were transferred to a PL pH 5.5 medium (- - ) and PL pH 5.5 medium added with $0.4 \mathrm{M}$-sucrose $(-\infty), 0.05 \mathrm{M}-\mathrm{MgCl}_{2}(\square-\square)$ or $0 . \mathrm{I} \mathrm{M}-\mathrm{NaCl}(\mathrm{O}-\mathrm{O})$, and incubated at $4 \mathrm{I}^{\circ} \mathrm{C}$ without shaking. At regular time intervals the viable count (a) and the O.D. (b) were determined.

allowed the round cells incubated in PL pH 5.5 to grow immediately and with a growth curve similar to that obtained in the same medium supplemented with $\mathrm{NaCl}, \mathrm{MgCl}_{2}$ or sucrose. In addition, spermine prevents the formation of filaments after extended incubation ( $12 \mathrm{~h}$ at $37^{\circ} \mathrm{C}$ ) and allows the formation of uniform and regular rods after 4 to $6 \mathrm{~h}$. 


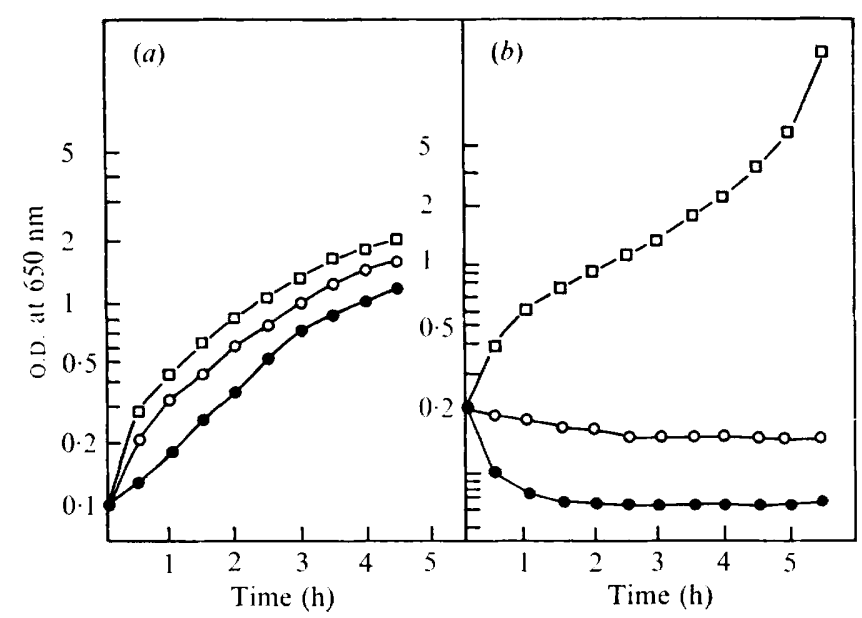

Fig. 8. Effect of deoxycholate at various concentrations on the growth of Mir A12 (a) and of mutant Mir $\mathrm{M}_{7}(b)$. Cells of the two strains were incubated in $\mathrm{PL} \mathrm{pH} 7$ medium to log phase and transferred to $\mathrm{PL} \mathrm{pH} 7(\square-\square)$ and to $\mathrm{PL} \mathrm{pH} 7$ containing sodium deoxycholate at $0 . \mathrm{I} \%(\mathrm{O}-\mathrm{O})$ and $0.5 \%(-)$ ) and incubated at $37^{\circ} \mathrm{C}$ without shaking. At regular time intervals the O.D. of the culture was determined.

\section{Revertants}

Three groups of revertants were isolated according to three different criteria: (i) The greater resistance of the rod-shaped cells to the action of rapid freezing and thawing was utilized; bacteria having a normal morphology were selected. (ii) Revertants were isolated by their ability to grow at $42{ }^{\circ} \mathrm{C}$. (iii) Bacteria were selected which were resistent to the effect of a mixture of DL-amino acids, which caused lysis only of the round cells, without effect on rod-shaped cells or on the wild type. Such behaviour has been correlated with the function of specific permeases (Cohen \& Monod, 1957) in the membrane. Therefore, in a population of round-shaped cells incubated in the presence of DL-methionine, only revertants with a normal membrane may grow.

By these methods all revertants isolated were found to possess a stable rod-shaped morphology, the ability to divide regularly at $42{ }^{\circ} \mathrm{C}$, and an insensitivity to DL-methionine or deoxycholate. The simultaneous recovery of membrane function, morphology and cell division, is consistent with the existence of a single pleiotropic mutation.

\section{DISCUSSION}

The present paper confirms and extends an earlier communication from this laboratory which showed that mutant Mir M7 exhibits disturbed morphology (Meloni \& MontiBragadin, 1962; Satta et al. 1969), forming round cells when grown at a $\mathrm{pH}$ above 7 but normal rod shapes at $\mathrm{pH}$ values below 7 .

Several observations suggest that the round morphology is associated with a weakening and/or a disorganization of the rigid layer of the cell wall. In fact Mir $\mathrm{M}_{7}$ round cells are much more fragile than the rod-shaped cells of both the mutant and the wild type. They are easily lysed by freezing and thawing, and by mild sonication (R. Fontana \& G. Satta, unpublished). Growing under conditions in which division is inhibited, for example at $4 \mathrm{I}{ }^{\circ} \mathrm{C}$ or in the presence of penicillin or nalidixic acid ( $R$. Fontana \& G. Satta, unpublished), they form giant polymorphous cells at $\mathrm{pH} 7$ and long filaments at acid $\mathrm{pH}$. Increasing the $\mathrm{pH}$ above 7 
yields larger and larger round cells; at $\mathrm{pH} 8$ spheroplast-like cells are formed. Also at $\mathrm{pH}$ values of 6 and $7 \cdot 5$, the mutant grows respectively as rods and as polymorphous round cells although the growth rate is higher at the acid $\mathrm{pH}$.

The Mir M7 strain also shows disturbances in cell division, which probably depend upon a damaged envelope. Evidence which supports this possibility includes the effects of sucrose, $\mathrm{Mg}^{2+}$ ions, $\mathrm{Na}^{+}$ions and spermine, which prevent the inhibition of the division of round and rod-shaped cells (or Mir $\mathrm{M}_{7}$ strain) at $4 \mathrm{I}{ }^{\circ} \mathrm{C}$ and eliminate the $2 \mathrm{~h}$ lag and the drop in viable count which characterizes the growth curve of round cells at 37 and $4 \mathrm{I}$ "C (Satta \& Fontana, 1974). It is already known that sucrose and $\mathrm{Mg}^{2+}$ ions can support the cytoplasmic membrane of fragile cells, spheroplasts and protoplasts (MacQuillen, I 960), spermine has been recognized to have specific protective action on membranes (Cohen \& Lichtenstein, I960; Mager, I959a, $b$; Puck, I960), and Hirota, Ryter \& Jacob (1968) have demonstrated an envelope damage in a temperature-sensitive cell division mutant in which the blockage of cell division can be relieved by the addition of $\mathrm{NaCl}$ (Shapiro ef al. I970; Siccardi et al. I971). Nagel de Zwaig \& Luria (1967), Holland \& Holland (1970), Samson \& Holland (1970), and Rolfe \& Onodera (1971) described enhanced sensitivity to deoxycholate in colicin-tolerant mutants of $E$. coli, the last two named finding an alteration in the protein composition of the membrane, while Hirota et al. (1969, 1970) described a cell division mutant which again showed greater deoxycholate sensitivity and a change in membrane protein composition. We similarly find that round Mir $\mathrm{M}_{7}$ cells are prone to lysis in the presence of deoxycholate at a concentration which has no effect on the Mir Ar 2 strain.

It is known that the membrane is involved in cell wall synthesis (Rogers, 1970) and the observations described above for the effects of $\mathrm{Mg}^{2+}, \mathrm{Na}^{+}$, spermine and deoxycholate suggest that the damage of the division is the result of an envelope defect. Damaged envelope would then be responsible for the $\mathrm{pH}$-dependent alteration of the morphology and for the temperature-dependent inhibition of division. The reversion experiments suggest that in Mir $M_{7}$ strain a single mutation is responsible for the damage to the envelope, alteration of the morphology and disturbance of cell division.

We are most grateful to Dr H. J. Rogers for very kindly reading the manuscript and for his useful criticism, advice and discussions. Very useful to us also were stimulating discussions with Dr H. Pooley and the suggestions he made. The kind help that Carla Olivari gave us in planning and doing experiments is also gratefully acknowledged.

\section{REFERENCES}

Boylan, R. J. \& Mendelson, N. H. (1969). Initial characterization of a temperature-sensitive rod mutant of Bacillus subtilis. Journal of Bacteriology roo, I 3 I 6-1 321 .

CoHen, G. N. \& Monod, J. (1957). Bacterial permeases. Bacteriological Reviews 21, I69-I 94.

Cohen, S. S. \& Lichtenstein, J. (I960). Polyamines and ribosome structure. Journal of Biological Chemistry 235, 776-782.

Cole, R. M., Popkin, T. J., Boylan, R. J. \& Mendelson, N. H. (I970). Ultrastructure of a temperaturesensitive rod ${ }^{-}$mutant of Bacillus subtilis. Journal of Bacteriology 103, 793-810.

DonaChIE, W. D. \& BeGG, K. J. (1970). Growth of the bacterial cell. Nature, London 227, I220-1224.

Grula, E. A. \& KING, R. D. (I970). Inhibition of cell division in Micrococcus lysodeikticus dis. II. Canadian Journal of Microbiology 16, 31 7-324.

Hirota, Y., MORdoh, J. \& J J Thermosensitive mutants of Escherichia coli altered in the process of DNA initiation. Journal of Molecular Biology 53, 369-387. 
Hirota, Y., Ryter, A. \& JACOB, F. (I968). Thermosensitive mutants of Escherichia coli affected in the processes of DNA synthesis and cellular division. Cold Spring Harbor Symposia on Quantitative Biology 33, 677-693.

Hirota, Y., Wakil, S., Shapiro, B., Ryter, A., Hurwitz, J. \& Jacob, F. (1969). Sur un mutant thermosensible d'Escherichia coli présentant des anomalies de la membrane. Comptes rendus de l'Académie des sciences D 269, $1346-1348$.

Holland, E. M. \& Holland, I. H. (1970). Induction of DNA breakdown and inhibition of cell division by colicin E2. Nature of some early steps in the process and properties of the E2-specific nuclease system. Journal of General Microbiology 64, 223-239.

INOUYE, M. \& PARDEe, A. B. (I970). Changes of membrane proteins and their relation to deoxyribonucleic acid synthesis and cell division of Escherichia coli. Journal of Biological Chemistry 245, 58I3-5819.

JACOB, F., Brenner, S. \& CuzIN, F. (I963). On the regulation of DNA replication in bacteria. Cold Spring Harbor Symposia on Quantitative Biology 28, 329-337.

MACQuillen, K. (1960). Bacterial protoplasts. In The Bacteria, vol. I, pp. 249-359. Edited by I. C. Gunsalus \& R. Y. Stanier. New York: Academic Press.

MAgER, J. (1959a). Spermine as a protective agent against osmotic lysis. Nature, London 183, 1827-1828.

MAGER, J. (1959b). The stabilizing effect of spermine and related polyamines on bacterial protoplasts. Biochimica et biophysica acta 36, 529-53I.

Meloni, G. A. \& Montr-Bragadin, C. (I962). Osservazioni sull'isolamento dall'uomo di sferoplasti 'spontanei' derivati da un ceppo di Klebsiella. Annali Sclavo 4, I43-I 52.

NAGEL DE ZwAIG, R. \& LURIA, S. E. (1967). Genetics and physiology of colicin-tolerant mutants of Escherichia coli. Journal of Bacteriology 94, 111 I2-I 123.

PuCK, C. W. (I960). The stabilizing effect of spermine and related amines on mitochondria and protoplasts. Biochemical and Biophysical Research Communications 2, 1 $17-120$.

Rogers, H. J. (1970). Bacterial growth and the cell envelope. Bacteriological Review's 34, I94-214.

Rogers, H. J., MacConnell, R. \& Burdett, J. D. (1970). Isolation and characterization of mutants of Bacillus subtilis and Bacillus licheniformis with disturbed morphology and division cell. Journal of General Microbiology 6r, I55-171.

ROLFe, B. \& ONODERA, K. (I97I). Demonstration of missing membrane proteins in colicin-tolerant mutant of E. coli KI2. Biochemical and Biophysical Research Communications 44, 767-773.

RYTER, A. (1967). Relationship between synthesis of the cytoplasmic membrane and nuclear segregation in Bacillus subtilis. Acta microbiologica Academiae scientiarum hungaricae 12, 284-290.

RYTER, A. (I971). Étude de la croissance de la membrane chez Bacillus subtilis au moyen de la distribution des flagelles. Annales de l'Institut Pasteur de Lille 121, 27 I-288.

Samson, A. C. R. \& Holland, I. B. (1970). Envelope protein changes in mutants of Escherichia coli refractory to colicin E2. FEBS letters II, 33-36.

Satta, G. \& Fontana, R. (I974). Cell division, macromolecular synthesis and morphology dependent on the state of the envelope in a mutant of Klebsiella pneumoniae. Journal of General Microbiology 8o, $65-75$.

Satta, G., Schito, G. C. \& Meloni, G. A. (1969). Transizione bastoncinosfera in un ceppo di Klebsiella pneumoniae. Ultrastruttura delle forme coccoidi tipiche ed abnormi. Atti del $X V^{\circ}$ Congresso Nazionale di Microbiologia Torina-Saint Vincent, vol. 2, pp. 247--253.

Schachtele, C. F., Anderson, D. L. \& Rogers, P. (1968). Mechanism of canavanine death in Escherichia coli. II. Membrane-bound canavanyl-protein and nuclear disruption. Journal of Molecular Biology 33, $86 \mathrm{i}-872$.

Schwarz, U., Asmus, A. \& Frank, H. (1969). Autolytic enzymes and cell division of Escherichia coli. Journal of Molecular Biology 4r, 4I9-429.

Shapiro, B. M., Siccardi, A. G., Hirota. Y. \& JaCOB, F. (1970). On the process of cellular division in Escherichia coli. Il. Membrane protein alterations asscciated with mutations affecting the initiation of DNA synthesis. Journal of Molecular Biology 52, 75-89.

Siccardi, A. G., Shapiro, B. M., Hirota, Y. \& JaCOB, F. (1971). On the process of cellular division in Escherichia coli. IV. Altered composition and turnover of the membranes of thermosensitive mutants defective in chromosomal replication. Journal of Molecular Biology 56, 475-490.

Walker, J. R. \& PARdef, A. B. (1968). Evidence for a relationship between deoxyribonucleic acid metabolism and septum formation in Escherichia coli. Journal of Bacteriology 95, 123-131. 